Original article

\title{
Geographic variation in Varroa jacobsoni (Acari, Varroidae) : application of multivariate morphometric techniques
}

\author{
M. Delfinado-Baker ${ }^{1}$ and M. A. Houck ${ }^{2}$ \\ 1 Beneficial Insects Laboratory, ARS/USDA, Bldg. 476, Barc-East, Beltsville, Maryland 20705 USA; \\ 2 Department of Ecology and Evolutionary Biology, University of Arizona, Tucson, AZ 85721 USA
}

(received 27 February 1989, accepted 2 June 1989)

Summary - Varroa jacobsoni is an ectoparasitic mite which attacks the honey bees Apis mellifera and Apis cerana. A morphological and taxonomic study was conducted using 462 female mites collected from $A$. mellifera and $A$. cerana from 17 countries (including two recent introduction sites in the United States). Thirteen morphological characteristics were measured.

While univariate analyses indicated a statistically significant difference in mean body length of $V$. jacobsoni collected from $A$. mellifera and $A$. cerana, the distributions overlapped broadly with a weak bimodality (by host). There was a weak correlation, on average, between the size of $V$. jacobsoni and the size of the host. However, there was sufficient size variance and plasticity that shifts in mite body size could accomodate interspecific host shifts.

Principal component analysis, discriminant function analysis and clustering (UPGMA) of Mahalanobis distances were used to determine phenetic similarity among populations. Results indicated that populations of $V$. jacobsoni show remarkable stability in character variance across their geographic range. There is no reason to suspect the occurrence of more than one cosmopolitan species. Since the US samples were more similar of $V$. jacobsoni collected from Brazil, than to European or Asian populations, it was concluded that the origin of the introduction into the United States was South America. The origin of the US introduction is discussed in terms of evolutionary implications and potential virulence of biotypes.

Varroa jacobsoni - morphometrics - geographic variation - multivarlate analysis

\section{Introduction}

The Asian honey bee mite, Varroa jacobsoni Oud. (Acari : Varroidae), is an obligate ectoparasite which attacks the honey bees Apis cerana Fabr. (Asian or Indian honey bee) and Apis mellifera $L$.
(European honey bee) (Eickwort, 1988). Apis cerana is the smaller of the two bee species, and is the original host of $V$. jacobsoni (Oudemans, 1904; DelfinadoBaker, 1988). The two hosts, A. cerana and $A$. mellifera, represent genetically isolated gene pools which are allopatric and do not naturally coexist over the 
extent of their ranges (Ruttner and Maul, 1983). Apis mellifera however, has been successfully introduced into many regions, including Southeast Asia (with the exception of Sri Lanka, Nepal, and probably Sumatra), imposing an artificial sympatry on both bee and mite distributions. Because of man's intervention and apicultural practices, $V$. jacobsoni is now almost cosmopolitan in distribution, occurring in all temperate and tropical regions of the world except Central and South Africa, Australia and New Zealand (Griffiths and Bowman, 1981). Until recently, $V$. jacobsoni had not bee present in Central or North America. In September 1987, however, mites were found in the state of Wisconsin. By May, 1988 , V. jacobsoni has been reported in fourteen states : Florida, Illinois, Indiana, Maine, Michigan, Mississipi, Nebraska, New York, Ohio, Pennsylvania, South Carolina, South Dakota, Washington and Wisconsin. The origin of the United States introduction is unknown, but the most likely possibilities are that the mites arrived on bees entering from South America or on bees attending unspecified queens shipped illegally from Europe or Asia.

Varroa jacobsoni has secondarily become a successful parasite of $A$. mellifera where the two bee species experience geographic proximity. The coevolutionary association of $V$. jacobsoni and $A$. cerana has resuited in hostparasite accommodation and reduce mortality to $A$. cerana colonies (Peng and Fang, 1988). In contrast A. mellifera, without benefit of a long historical association, experiences hive mortality as a common outcome of infestation. This difference in mortality results, in part, from the fact that $V$. jacobsoni usually confines its feeding to drone brood of $A$. cerana, but attacks both drone and worker brood of $A$. mellifera (Koeniger et al., 1981; De
Jong, 1988). Reduced infestation on $A$. cerana is also due to worker recognition of Varroa and the removing of mites from their bodies (Peng et al., 1987; Peng and Fang, 1988), to juvenile hormone titers in $A$. cerana females which are insufficient to stimulate ovulation in the mite (Hänel, 1983), and perhaps to a shorter postcapping developmental period (Schousboe, 1986). Loss of potential workers in domestic $A$. mellifera hives threatens all functions of the hive, and has become a serious threat to commercial beekeeping and pollination biology.

Morphological studies of $V$. jacobsoni have been pursued to better understand the biology, systematics and geographic variation of this mite (Delfinado and Baker, 1974; Delfinado-Baker, 1984; Grobov et al., 1980; Akimov and Yastrebtsov, 1985; Akimov et al., 1988). Varroa jacobsoni was found to be morphologically conservative, and best diagnosed on the basis of female characters. In general, mites from the smaller bee species, $A$. cerana, appear to be smaller than those from $A$. mellifera (Delfinado-Baker, 1988). While geographic variability in body size, shape, and chaetotaxy exists among females of V. jacobsoni, conventional approaches have yielded no features useful for taxonomic identification and discrimination of mites collected from $A$. mellifera and $A$. cerana. Because mite behavior and infestation-impact differ in $V$. jacobsoni associated with $A$. mellifera and $A$. cerana, it has been suggested that $V$. jacobsoni may represent a species complex, as has been shown in other acarines (Griffiths et al., 1983).

This study is an extension of previous morphological work on $V$. jacobsoni and addresses three issues :

- whether multivariate morphological procedures are useful in interpreting 
patterns of character variation and covariation in mites associated with $A$. mellifera and $A$. cerana ;

- whether multivariate patterns of morphological variation in $V$. jacobsoni can be differentiated by country or region of collection; and

- whether the origin of the populations introduced into the United States can be clarified with any degree of certainly on grounds of morphological similarity.

\section{Materials and Methods}

\section{Samples and characters}

462 females of Varroa jacobsoni were collected from Apis cerana $(N=92)$ and Apis mellifera $(N=370)$ from 17 countries representing 5 geographic regions (Table I). Among these, two recent introduction-sites in the United States (Wisconsin and Florida) were sampled.

Mites were processed in $5 \% \mathrm{KOH}$ and mounted in Hoyer's medium. Characters were measured using a phase contrast microscope

Table 1. Geographic regions, countries, and species of Apis from which Varroa jacobsoni were collected.

\begin{tabular}{|c|c|c|c|}
\hline Geographic region & Country & $\mathrm{N}$ & Species of Apis \\
\hline $\begin{array}{l}\text { Old world : } \\
\text { Europe }\end{array}$ & $\begin{array}{l}\text { Germany (1977) } \\
\text { Poland (1980) } \\
\text { USSR (1964) } \\
\text { Netherlands (1983) }\end{array}$ & $\begin{array}{l}28 \\
25 \\
28 \\
27\end{array}$ & $\begin{array}{l}\text { Apis mellifera } \\
\text { Apis mellifera } \\
\text { Apis mellifera } \\
\text { Apis mellifera }\end{array}$ \\
\hline Mediterranean & $\begin{array}{l}\text { Tunisia (1975) } \\
\text { Iran (1978) } \\
\text { Israel (1984) }\end{array}$ & $\begin{array}{l}31 \\
31 \\
26\end{array}$ & $\begin{array}{l}\text { Apis mellifera } \\
\text { Apis mellifera } \\
\text { Apis mellifera }\end{array}$ \\
\hline Asia & $\begin{array}{l}\text { Nepal } \\
\text { Sri Lanka (1983) } \\
\text { Malaysia (1963) } \\
\text { Thailand (1968) } \\
\text { China (1958) } \\
\text { Korea (1960) } \\
\text { P. New Guinea (1986) } \\
\text { Philippines (1960) }\end{array}$ & $\begin{array}{l}17 \\
36 \\
14 \\
25 \\
23 \\
28 \\
24 \\
24\end{array}$ & $\begin{array}{l}\text { Apis cerana } \\
\text { Apis cerana } \\
\text { Apis cerana } \\
\text { Apis cerana } \\
\text { Apis mellifera } \\
\text { Apis mellifera } \\
\text { Apis mellifera } \\
\text { Apis mellifera }\end{array}$ \\
\hline $\begin{array}{l}\text { New World: } \\
\text { North America }\end{array}$ & $\begin{array}{l}\text { USA : Wisconsin (1987) } \\
\text { USA : Florida (1987) }\end{array}$ & $\begin{array}{l}23 \\
28\end{array}$ & $\begin{array}{l}\text { Apis mellifera } \\
\text { Apis mellifera }\end{array}$ \\
\hline \multirow[t]{2}{*}{ South America } & Brazil (1978) & 24 & Apis mellifera \\
\hline & Total & 462 & \\
\hline
\end{tabular}

Groupings by region are consistent with Figures $4,6 \mathrm{~B}$ and $7 \mathrm{~B}$. Dates following country designations are dates of detection of $V$. jacobsoni. 
equipped with ocular micrometer. Bilateral measurements were averaged for each specimen.

Morphological characters (Fig. 1) measured included : maximum body length, maximum body width, the distance between the first pair of sternal setae (ST1), the distance between the second pair of sternal setae (ST2), the width of the genital shield, the width of the anal shield, the distance between the first and second pairs of sternal setae, the width of the metapodal shield, the length of the metapodal shield, the length of the tarsus of leg $I$, the number of sternal setae, the number of dorsal shield marginal setae, and the number of metapodal marginal setae. All distances are in micrometers.

\section{Statistical procedures}

Body size was examined as a univariate character (body length) and as a latent variable (general size) contributing to character variance. A Manova procedure using the General Linear Model was used to estimate the influence of geographic region and Apis hostspecies on morphological characters. The Tukey studentized range test on all main-effect means determined statistical differences among groups $(\alpha=0.05)$.

Principal components analysis (PCA), based on the covariance matrix of log-

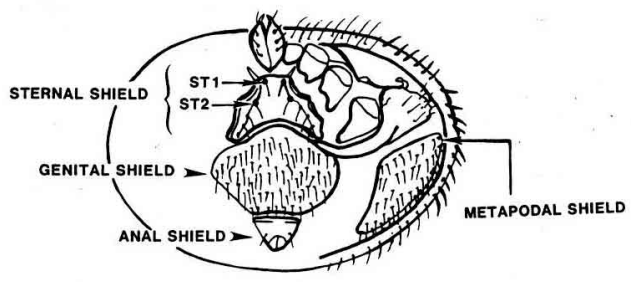

Fig. 1. Distance measured across the form of Varroa jacobsoni females. For taxonomic details see Delfinado and Baker (1974). transformed data, was performed and multivariate allometric coefficients calculated. Character lengths were first converted to natural logarithms to equalize variances, preserve (linearize) allometric relationships among characters, and produce a scaleinvariant covariance matrix. Because we wished to examine patterns of variation independent of differences in body size, size was partitioned from the data set on a character-by-character basis in the following manner. The first eigenvector of the PCA represents a general-size factor, derived from the within-group variance-covariance matrix. Each log-transformed character was independently regressed on this size factor (PC1). The size-free residuals were calculated and a discriminant function analysis (DFA) was subsequently performed, by group, on these residuals. The scores were then plotted as scattergrams. This provided interpretation of morphological patterns in form as size-free contrasts, independent of the allometric consequences of size change.

Centroids ( \pm 1 SD) of the scores of individuals on DF1 and DF2 were calculated by country and by extended geographic region (i.e. Europe, Mediterranean, Asia, North and South America). Centroid analysis characterizes the "average" individual variance on DF1 and DF2 for the size-corrected data. This point, and one standard deviation about this point, represents the focus about which individuals vary in multivariate space.

Mahalanobis distances (D2) were calculated among groups on the primary discriminant axes (DF1 and DF2) and a clustering algorithm (UPGMA) was used to determined phenetic similarities, by country and region. Resulting dendrograms are not interpretable as statements of phylogenetic relationships because they do not distinguish primitive from derived similarity.

A 3-D contour plot of the centroids of DF1DF3 ( \pm 1 SD) was constructed to visually show the continuity in morphology across the geographic range of $V$. jacobsoni. The first three components were used because the variance structure reflected in DF4, and beyond, was minimal and reflected nonbiological (measurement) variance.

The SAS - PC statistical package was used on an IBM PC/AT microcomputer for calculation of univariate means, the Manova and the PCA. The DFA procedures were run on mainframe SAS using a VAX system. 


\section{RESULTS}

The difference in mean body length of Varroa jacobsoni collected from Apis cerana (mean $=1037.52 \mu \mathrm{m} \pm 49.38$ ) and from Apis mellifera (mean $=1$ 106.31 $\mu \mathrm{m} \pm 33.19)$ is statistically significant $\left(F_{12,440}=8.91 ; P \geq F=0.0001\right)$, while the distributions of body length overlap broadly with a weak bimodality by host (Fig. 2A). The frequency distribution of general-size (scores of PC1) parallels that of body length for $V$. jacobsoni collected from $A$. mellifera and $A$. cerana (Fig. 2B)
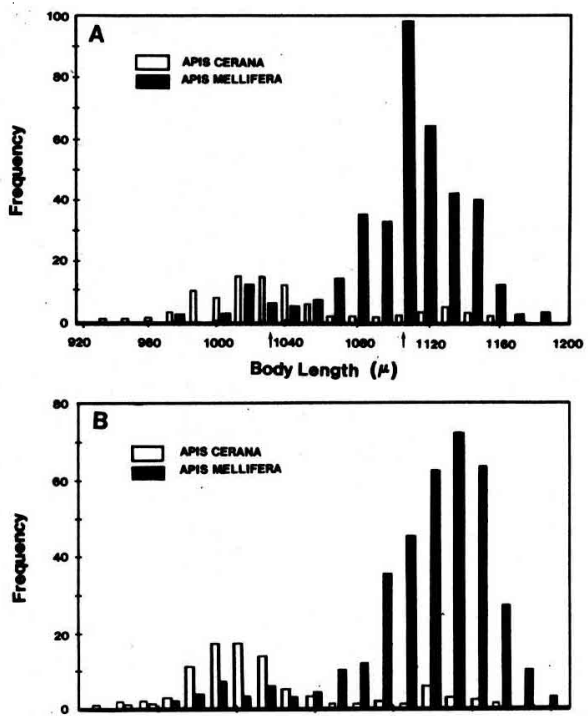

General Size

Fig. 2 A. Frequency distribution of body length $(\mu \mathrm{m})$ of Varroa jacobsoni collected from Apis cerana and Apis mellifera. Means are indicated by arrows along the abscissa. Although the mean body length for mites on $A$. cerana (mean $=1037.52 \mu \mathrm{m} \pm 49.38$ ) is statistically less than that on A. mellifera (mean $=1106.31$ $\mu \mathrm{m} \pm 33.19$ ), the distributions overlap with a weak bimodality by host.

B. Frequency distribution of general size (PC1) of $V$. jacobsoni collected from $A$. cerana and A. mellifera. The PCA was based on the covariance matrix of log-transformed data. indicating that size is the first component in PCA.

The PCA offered no separation or resolution of groups. The first eigenvector accounted for $38 \%$ of the total variance, while the second accounted for $28 \%$. All allometric coefficients reflected positive allometry of characters except for the distance between the first pair of sternal setae and the number of metapodal marginal setae. These two characters exhibited a decrease in magnitude with an increase in general size.

When weighted by cauntry, the primary size-free discriminant axis (DF1) accounted for $36 \%$ of the variance structure, while DF2 accounted for $21 \%$. The remainder of the variance was relatively equally partitioned among the remaining functions. Significant character coefficients (expressed as correlations of characters with discriminant functions) demonstrate that the length of the metapodal shield (0.57), the length of tarsus $1(-0.67)$, and the number of metapodal setae $(0.45)$ contribute most to the size-free discrimination.

Discriminant function analysis, by country (Fig. 3), resulted in discrimination among only nine of the 153 pair-wise comparisons $(5.9 \%)$ (Table II). This level of discrimination is not dissimilar to that expected due to sampling error alone (where $\alpha=0.05$ ).

When examined by region (Fig. 4), DF 1 accounted for $75 \%$ of the variance in the data set and DF2 accounted for $19 \%$, with regions not discriminated on any axis. Character variance overlapped on DF1 and DF2 with no indication of discriminatory pattern. In addition, no discrimination could be assigned to host (Fig. 5). The primary axes of DFA by hostspecies accounted for $100 \%$ variance (as is always the case for a two-group comparison). 


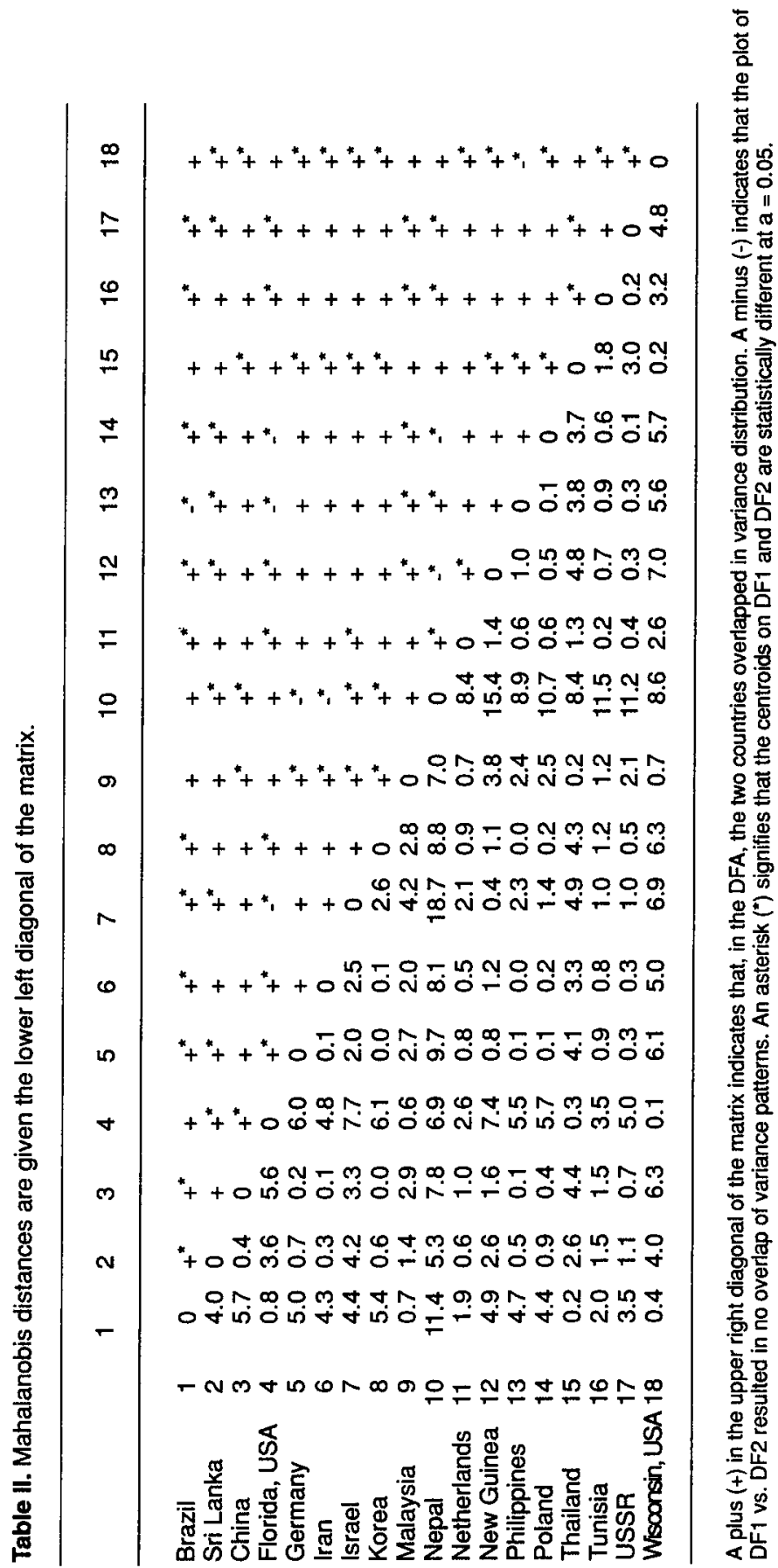




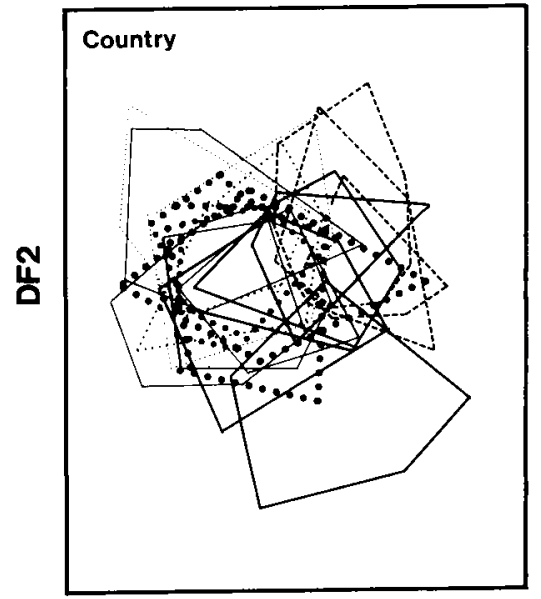

DF 1

Fig. 3. Primary and secondary DFA scores, plotted by country of origin, for Varroa jacobsoni. Data are pooled across hostspecies. Populations which have nonoverlapping distributions are indicated in Table II.

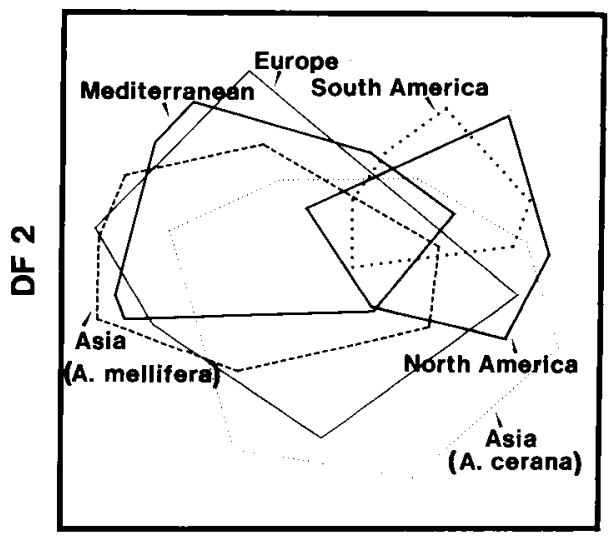

DF 1

Fig. 4. Primary and secondary discriminant function scores, plotted by region, for Varroa jacobsoni. Data are pooled across hostspecies.

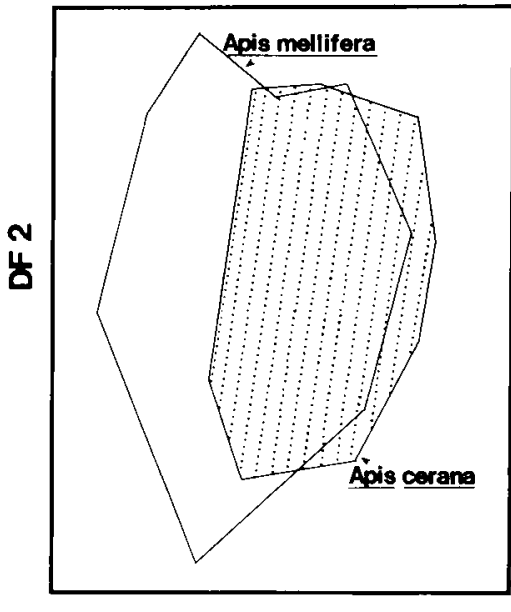

\section{DF 1}

Fig. 5. Primary and secondary DFA scores, plotted by host-species, for Varroa jacobsoni. Data are pooled across countries of collection.

Further structure in the data was resolved by centroid analysis. Centroids ( $\pm 1 \mathrm{SD}$ ) of the character-distributions on DF1 and DF2 were plotted by country and by region (Fig. 6A,B). Significant differences among centroids occurred in $49.7 \%$ of the comparisons (Table II) and reflected character shifts, among populations, following mite establishment.

Mites from Nepal (Fig. 6A) are distinctly different from all others. Varroa jacobsoni from Brazil, Wisconsin, and Florida form a cluster and are more similar to one another than each is to any other population. The Mediterranean and European localities (Fig. 6B) provide only slight character contrast when compared with other groups. Phenetic cluster analysis among regions (Table III, Fig. 7 $A, B)$ indicates that mites from North America (Wisconsin and Florida) are most similar in morphology to those of South America $\left(D^{2}=1.16\right)$. 

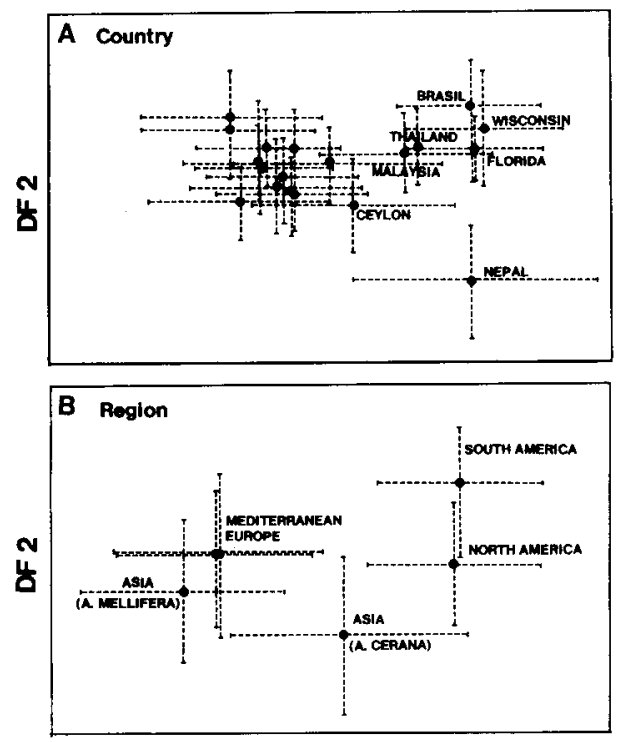

DF 1

Fig. 6A. Centroids ( \pm 1SD) of the primary and secondary discriminant functions, calculated by country, for Varroa jacobsoni. 6B. Centroids $( \pm$ $1 \mathrm{SD})$ of the primary and secondary discriminant functions, calculated by region, for Varroa jacobsoni. Centroid analysis positions the "average" individual variance on DF1 and DF2 for the size-corrected data. This point, and one standard deviation about this point, represent the focus about which variation rotates in multivariate space.

\section{Discussion}

The difference in mean body length of Varroa jacobsoni collected from Apis cerana and Apis mellifera is statistically significant, while the distributions of body length overlap broadly. The smallest mites from $A$. mellifera overlap the central tendency of those from $A$. cerana and vice versa. This indicates that there is a weak correlation, on average, between the size of $V$. jacobsoni and the size of the host. However, there is sufficient size variance and plasticity that shifts in mite body size could accomodate interspecific host shifts.

The smallest mites occurred on $A$. cerana from Sri Lanka. It is interesting that the largest specimens of $V$. jacobsoni were those from Nepal (mean = $1125.58 \mu \mathrm{m} \pm 20.66$ ). These mites were removed from the same bees from which the type-specimens of Varroa underwoodi were obtained (DelfinadoBaker and Agganwal, 1987). Apis cerana is the natural host for both $V$. jacobsoni and $V$. underwoodi. Sympatry of the mite species may have resulted in character displacement for body size, since $V$. underwoodi is about $20 \%$ smaller on

Table III. Mahalanobis distances among regions from which Varroa jacobsoni were collected.

\begin{tabular}{|c|c|c|c|c|c|c|c|}
\hline & & 1 & 2 & 3 & 4 & 5 & 6 \\
\hline Asia (Apis mellifera) & 1 & 0 & & & & & \\
\hline Europe & 2 & 2.5 & 0 & & & & \\
\hline Mediterranean & 3 & 2.6 & 0.0 & 0 & & & \\
\hline North America & 4 & 1.9 & 4.9 & 5.1 & 0 & & \\
\hline Asia (Apis cerana) & 5 & 2.6 & 0.3 & 0.3 & 6.6 & 0 & \\
\hline South America & 6 & 5.2 & 6.0 & 6.2 & 1.2 & 8.8 & 0 \\
\hline
\end{tabular}



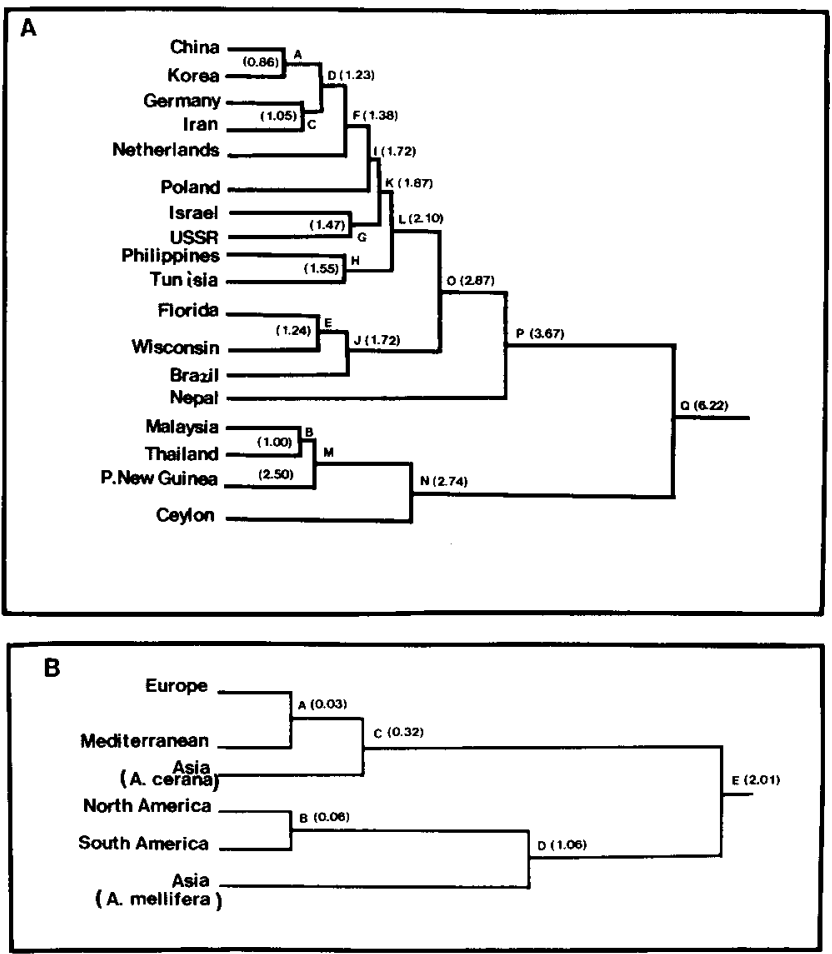

Fig. 7A. Cluster diagram of Mahalanobis distances, by country, for Varroa jacobsoni. Values in parentheses are the Mahalanobis distances. Branch lengths are proportional to these distances. 7B. Cluster diagram of Mahalanobis distances, by region, for Varroa jacobsoni. Values in parentheses are the Mahalanobis distances. Branch lengths are proportional to these distances.

average $($ mean $=758 \mu \mathrm{m})$ than the smallest $V$. jacobsoni (mean $=934 \mu \mathrm{m})$ collected from any locality in this study, and $V$. jacobsoni is most divergent in size in sympatry. This is a hypothesis which could be tested if additional mites in sympatry are compared with mites in allopatry.

These results, taken in concert and in context, indicate that populations of $V$. jacobsoni show remarkable stability in character variance across their geographic range with transitions in variation from continent to continent (Fig. 8). The observed morphological consistence may reflect a relatively short period of geographic isolation and/or diffuse and recurrent redistribution of domesticated A.mellifera. There is no reason to suspect the occurrence of more than one cosmopolitan species.

Because character deviation has presumably been weak since the radiation of $V$. jacobsoni from its area of origin, an examination of mean differences in multivariate character space was appropriate. Centroid analysis, Mahalanobis distances, and clustering methods indicate that the Wisconsin and Florida samples are more similar to $V$. jacobsoni 


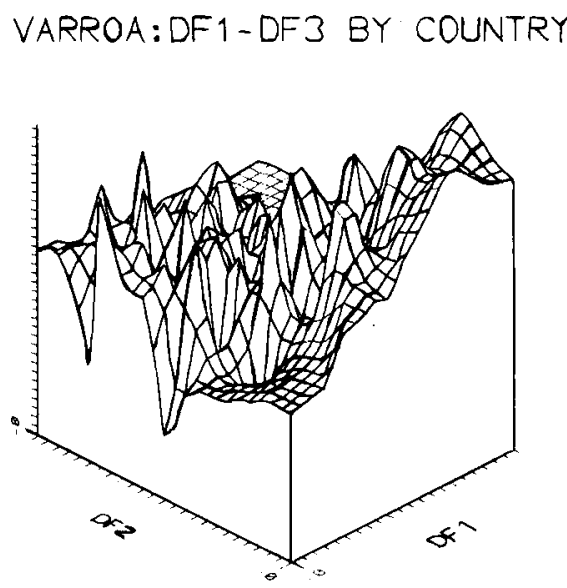

Fig. 8. Three-dimensional plot of centroids of scores $( \pm 1 S D)$ on DF1-DF3 for all characters. Each peak represents an individual country from which Varroa jacobsoni was collected. The transitions and nature of the variance structure represent non-discrete groupings.

collected from Brazil than they are to the European or Asian populations. The most parsimonious conclusion would be that the origin of the introduction into the United States was South America, and that the introduction was recent. The fact that character variation occurs among Brazilian and US mites indicates that either :

- the temporal separation of the Brazilian and US gene pools has provided sufficient time for real morphological divergence to occur, or

- that the observed variance reflects the sampling of hives in Brazil which are different from Brazilian hives contributing to the US introduction.

An auxiliary finding in this study is that the Mahalanobis distances portray the mites from Brazil as similar to the Asian lineage, and most likely not of European origin (Fig. 7A,B). This conclusion concerning transport route is quite realistic since samples of $V$. jacobsoni were known to have been carried to Paraguay in 1971 on queens and comb imported from Japan. Mites were subsequently introduced from apiaries in Paraguay to Brazil in 1972 (De Jong and Goncalves, 1981), producing the phenetic similarity of the Asian and South American mites.

This character analysis has offered several conclusions concerning $V$. jacobsoni that could not have been obtained by conventional methods. Through a multivariate approach we have determined the extent of morphological plasticity in $V$. jacobsoni, the phenetic relationships among sampled populations, and the probable origin of the introduction into North America. This study also establishes a data base for further evolutionary studies on the rangeextension and adaptation of a hostparasite association, and may contribute to the predictive power concerning the potential virulence of infestation in the United States.

Delfinado-Baker (1988) has identified three mite biotypes :

- Biotype A infests A. mellifera of European origin and parasitizes both drone and worker broods causing heavy losses in all European races of bees;

- Biotype $B$ infests $A$. cerana drone brood only and results in minimal colony damage; and

- Biotype $C$ infests both drone and worker brood of Africanized bees causing brood damage but usually not colony mortality, partly because of the shorter postcapping period (9.6-11 days), and hence shorter pupation period of the bees, and resulting restricted mite reproduction under these conditions (Camazine, 1986; Moritz and Hänel, 1984; Shousboe, 1986). Since the origin 
of infestation in North America is most likely Africanized Brazilian bees, these mites may be of less virulence than had they been derived from European parentage, if virulence is a reflection of mite biology. However, it is equally likely that biotypes reflect the host biology or some covariance parameters of host and parasite.

However encouraging this lesser evil may seem, the prospects for losses of bees, honey and migratory pollination services will continue to be high. Contributing to the overall problem is the paucity of available information concerning this mite's biology in the United States. Previous generalities developed under European and Asian climatic regimes, management practices, and breeding programs may not extrapolate to United States situations.

The European Economic Community (EEC) is the leader in Varroa research and development in both the basic and applied sciences (Bruce and Chiesa, 1988). Concentrated support for Varroa biology is needed in the United States, as well as workers willing to contribute their talents to a crisis likely to be a far more serious threat to apiculture and agriculture than any experienced so far in modern history.

\section{Acknowledgments}

We are especially grateful to the following for their valued collections of Varroa jacobsoni upon which this study is based : M. Burgett (Thailand); W. Chmielewski (Poland); H.A. Denmark (USA); W. Drescher (Germany); N.G. Koeniger (Sri Lanka); C.H.W. Flechtmann (Brazil); M.L. Lee (Korea); Y. Lensky (Israel); L.S. Li (China); M.S. Mossadegh (Iran); A.C.G. Phoon (Malaysia); A. de Ruijter (Netherlands); B. Underwood (Nepal); and A.V. Yastrebtsov (USSR).
We thank R.E. Strauss for his technical advice. We thank $H$. Shimanuki and $E$. Erickson for their support, cooperation and helpful information. S.W.T. Batra, E. Erickson, R.E. Strauss and an anonymous reviewer made helpful comments on the manuscript. This study was funded by : Binational Agricultural Research and Development Funds (BARD) Grant 58-32U4-028 to $\mathrm{M}$. DelfinadoBaker, BARD Grant \# 1-1397-87 and NSF Grant \# BSR-8307711 to M.A. Houck. Analyses of data were completed while one of us (MAH) was under cooperative agreement with the Carl Hayden Bee Laboratory, Tucson, Arizona. We wish to thank E. Erickson (director) for his support and cooperation.

Résumé - Variation géographique de Varroa jacobsoni (Acari, Varroidae) : application des techniques morphométriques multivariables. Varroa jacobsoni est un acarien ectoparasite qui attaque les abeilles Apis mellifica et Apis cerana. Les acariens sont une sérieuse menace pour la vigueur et la survie des colonies qu'ils infestent. En raison de l'infestation et du comportement de l'acarien différents selon l'hôte, on a pensé qu'il pouvait s'agir d'un complexe d'espèces avec une spécificité stricte de l'hôte. On a réalisé une étude morphologique et taxonomique des femelles adultes de $V$. jacobsoni provenant de divers hôtes récoltés dans diverses parties du monde. On décrit dans cet article la variabilité morphologique que présente $V$. jacobsoni sur les deux espèces d'abeilles. Avec les techniques morphométriques multivariables, on a examiné et mesuré 13 caractères morphologiques, chez les acariens femelles adultes, prélevés dans 17 localités à travers le monde, y compris deux endroits aux Etats-Unis. L'analyse en composantes principales, l'analyse de la fonction discriminante et la classification phénétique des distances de Mahalanobis ont été utilisées pour 
déterminer la ressemblance entre les échantillons. Les caractères étudiés sont les suivants : longueur du corps, largeur du corps, distance entre les setae sternaux de la $1^{\text {re }}$ paire, distance entre les setae sternaux de la $2^{e}$ paire, distance entre la tre et la $2^{e}$ paire de setae sternaux, largeur du sclérite épigynial, largeur du sclérite anal, largeur du sclérite métapodal, longueur du sclérite métapodal, longueur du tarse de la patte I, nombre de setae sternaux, nombre de setae dorsaux marginaux et nombre de setae métapodaux marginaux.

L'analyse des caractères a fourni plusieurs conclusions concernant la taxonomie de Varroa, impossibles à obtenir par les méthodes taxonomiques traditionnelles. Les techniques morphologiques multivariables ont permis de déterminer le degré de plasticité de $V$. jacobsoni et l'origine géographique de la souche introduite aux Etats-Unis. La différence dans la longueur moyenne du corps de $V$. jacobsoni sur Apis mellifica et Apis cerana est statistiquement significative, alors que les distributions de la longueur du corps des deux parasites se recouvrent largement. Les acariens les plus petits venant d'Apis mellifica recouvrent la tendance centrale de ceux qui viennent d'Apis cerana et vice versa. Les plus gros specimens de $V$. jacobsoni sont ceux du Népal sur Apis cerana; les plus petits viennent de Ceylan, sur Apis cerana aussi. L'ensemble des résultats indique que les populations de $V$. jacobsoni présentent une remarquable stabilité dans la variance des caractères sur toute leur aire de répartition géographique avec des transitions continues douces dans les variations d'un continent à un autre. II n'y a aucune raison pour suspecter l'existence de plus d'une espèce cosmopolite infestant Apis cerana et Apis mellifica. La méthode du centroïde, les distances de Mahalanobis et les méthodes de classification par agrégation montrent que les échantillons du Wisconsin et de Floride sont bien plus proches des $V$. jacobsoni prélevés au Brésil que de ceux des populations européennes ou asiatiques. On conclut que l'introduction aux Etats-Unis s'est faite à partir de l'Amérique du Sud. On discute l'origine de l'introduction en termes d'implications pour l'évolution et de virulence des biotypes.

Varroa jacobsoni - morphométrie variation géographique - analyse multivariable

\section{Zusammenfassung - Geographische} Variabilität von Varroa jacobsoni (Acari, Varroidae) : Analyse unter Verwendung multivariater morphometrischer Methoden. Varroa jacobsoni ist eine ektoparasitische Milbe, welche die Honigbienen Apis mellifera und Apis cerana anfältt. Die Milbe bedroht ernstlich Lebenskraft und Überlebenstähigkeit der Bienenvölker, die sie befällt. Da sowohl Befall wie Verhalten der Milbe auf beiden Bienenarten verschieden ist, wurde vermutet, $V$. jacobsoni könnte einen Artenkomplex mit enger Wirtsspezifität bilden. Deshalb wurde eine morphologische und taxonomische Untersuchung von weiblichen erwachsenen Milben aus verschiedenen Wirtsvölkern und aus verschiedenen Teilen der Erde vorgenommen.

In dieser Arbeit wird die morphologische Variabiltät von $V$. jacobsoni auf den beiden Bienenarten beschrieben. Unter Einführung von multivariaten morphologischen Techniken in die VarroaTaxonomie wurden 13 morphologische Merkmale von erwachsenen weiblichen Tieren aus 17 Ländern untersucht und 
gemessen, einschließlich zweier Orte in den Vereinigten Staaten. Zur Feststellung von Ähnlichkeiten zwischen den Proben wurden die statistischen Verfahren der Hauptkomponentenanalyse (PCA), Diskriminanzanalyse und der phänetischen Clusteranalyse (UPGMA) von Mahalonobis-Distanzen benutzt. Es wurden folgende Merkmale untersucht : Körperlänge, Körperbreite, Abstand zwischen dem ersten Paar sternaler Borsten, Abstand zwischen dem zweiten Paar sternaler Borsten, Abstand zwischen den ersten und den zweiten Paaren sternaler Borsten, Breite von Genital- und von Analfeld, Breite von metapodalem Feld, Tarsuslänge von Bein I, Anzahl der Sternalborsten, Anzahl der dorsalen Randborsten und Anzahl der metapodalen Randborsten (Fig. 1).

Diese Merkmalsanalyse hat einige Schlußfolgerungen zur Taxonomie von Varroa ermöglicht, die mit den konventionellen taxonomischen Methoden nicht zu erzielen sind. Die multivariaten morphologischen Techniken haben Angaben über die Variationsbreite und über ihren wahrscheinlichen Einwanderungsweg in die Vereinigten Staaten erbracht.

Der Unterschied in der mittleren Körperlänge von $V$. jacobsoni parasitierend auf Apis cerana und auf Apis mellifera ist statistisch signifikant, aber die Einzelwerte für die Körperlänge überlappen sich stark. Die kleinsten Milben auf Apis mellifera überlappen die mittleren Größen der Milben auf Apis cerana, und umgekehrt. Die größten Exemplare von $V$. jacobsoni wurden in Völkern von Apis cerana in Nepal gefunden; die kleinsten Milben kamen ebenfalls auf Apis cerana vor, und zwar auf Ceylon (Sri Lanka). Das Gesamtresultat zeigt eine bemerkenswerte Stabilität der Merkmalsvarianz der Populationen von $V$. jacobsoni über ihr geographisches Verbreitungsgebiet mit kontinuierlichen allmählichen Übergängen in der Variabilität von Kontinent zu Kontinent.

Es gibt keinen Grund für den Verdacht, daß mehr als eine einzige kosmopolitische Art existiert, die sowohl auf Apis cerana wie auf Apis mellifera parasitiert. Die Analyse der Zentroide, der Mahalonobis-Distanzen und der Resultate der Cluster-Analysen haben ergeben, daß die Proben aus Wisconsin und aus Florida der $V$. jacobsoni aus Brasilien ähnlicher waren als die Proben aus Europa und aus Asien. Es wird daraus der Schluß gezogen, daß die in die Vereinigten Staaten eingeschleppten Milben aus Südamerika stammen. Die Herkunft der Einschleppung wird unter dem Aspekt der evolutionären Bedeutung und der Virulenz der Milbenstämme diskutiert.

\section{Varroa jacobsoni - Morphometrie - geographische Variabilität - multi- variate Analyse}

\section{References}

Akimov I.A. \& Yastrebtsov A.V. (1985) Phenotypic variability of some features of the mite Varroa jacobsoni, a parasite of the honey bee. Dokl. Akad. Nauk SSSR, B, No. 8, 58-60 (in Russian)

Akimov I.A., Starovir I.S., Yastrebtsov A.V. \& Gorgol V.T. (1988) The Varroa mite - the causation agent of varroatosis of bees. A morphological outline. Naukova Dumka Kiev, UkrSSR 1-120 (in Russian)

Bruce B.A. \& Chiesa F. (1988) An artificial diet for Varroa jacobsoni. In: Proc. Int. Conf. on Africanized Honey Bees and Bee Mites (G. Needham, R. Page, M. Delfinado-Baker and C. Bowman, eds.), Ellis Horwood Limited, West Sussex, England

Camazine S. (1986) Differential reproduction of the mite, Varroa jacobsoni (Mesostigmata : 
Varroidae), on Africanized and European honey bees (Hymenoptera : Apidae). Ann. Entomol. Soc. Am. 79, 01-03

De Jong D. \& Goncalves L.S. (1981) The Varroa problem in Brazil. Am. Bee J. 121, 186189

De Jong D. (1988) Varroa jacobsoni does reproduce in worker cells of Apis cerana in South Korea. Apidologie 19, 241-244

Delfinado M.D. \& Baker E.W. (1974) Varroidae, a new family of mites parasitic on honey bees (Mesostigmata : Acarina). J. Wash Acad. Sci. 64, 154-163

Delfinado-Baker M.D. (1984) The nymphal stages and male of Varroa jacobsoni Oudemans a parasite of honey bees. Int. J. Acarol. 10, 75-80

Delfinado-Baker M.D. \& Aggarwal K. (1987) A new Varroa (Acari; Varroidae) from the nest of Apis cerana (Apidae). Int. J. Acarol. 13, 233237

Delfinado-Baker M.D. (1988) Variability and biotypes of Varroa jacobsoni Oudemans. Am. Bee J. 128, 567-568

Eickwort G.C. (1988) The origins of mites associated with honey bees. In : Proc. Int. Conf. on Africanized Honey Bees and Bee Mites (G. Needham, R. Page, M. DelfinadoBaker and C. Bowman, eds.), Ellis Horwood Limited, West Sussex, England

Griffiths D.A. \& Bowman C.E. (1981) World distribution of the mite Varroa jacobsoni, a parasite of honey bees. Bee World 62, 154-163

Griffiths D.A., Gray J. \& Pegazzano F. (1983) Varroa - the acaralogist's view. In : Proceedings of a Meeting of EC Expert's Group/ Wageningen. 7-9 February 1988 (R. Cavalioro, ed.), pp. 79-83

Grobov O.F., Pulenets N.M. \& Sofronov C.L. (1980) Geographical variability of the size of the dorsal scutellum in females of Varroa jacobsoni Oud. Proc. XXVII Int. Beekeeping Congr., Athens, 1979. Bucharest, Apimondia, 346-350

Hänel H. (1983) Effect of JH III on the reproduction of Varroa jacobsoni. Apidologie 14, 137-142

Koeniger N., Koeniger G. \& Wijayagunasikara N.H.P. (1981) Beobachtungen Über die Anpassung von Varroa jacobsoni an ihren natürlichen Wirt Apis cerana in Sri Lanka. Apidologie 12, 37-40

Moritz R.F.A. \& Hänel H. (1984) Restricted development of the parasitic mite Varroa jacobsoni Oud. in the Cape honey bee Apis mellifera capensis Esch. Z. Angew. Entomol. 97, 91-95

Oudemans A.C. (1904) On a new genus and species of parasitic Acari. Notes Leyden Mus. 24, 216-222

Peng Y.S.C., Fang Y. \& Ge L. (1987) The resistance mechanism of the Asian honey bee Apis cerana Fabr. to an ectoparasitic mite Varroa jacobsoni. J. Invertebr. Pathol. 49, 5460

Peng Y.S.C. \& Fang Y. (1988) Removal of the mite Varroa jacobsoni from the brood of the European honey bee Apis mellifera in foster colonies of the Asian honey bee Apis mellifera. In : Proc. Int. Conf. on Africanized Honey Bees and Bee Mites (G. Needham, R. Page, M. Delfinado-Baker and C. Bowman, eds.), Ellis Horwood Limited, West Sussex, England, pp. 572

Ruttner F. \& Maul V. (1983) Experimental analysis of reproductive interspecies isolation of Apis mellifera L. and Apis cerana Fabr. Apidologie 14, 309-327

Schousboe C. (1986) The duration of the sealed cell stage in worker honey bee brood in relation to increased resistance to Varroa jacobsoni. Tidsskr. Planteavl . 90, 293-299 